Article

\title{
Sinapic Acid Esters: Octinoxate Substitutes Combining Suitable UV Protection and Antioxidant Activity
}

\author{
Cédric Peyrot $^{+} \mathbb{D}$, Matthieu M. Mention ${ }^{+} \mathbb{D}$, Fanny Brunissen ${ }^{\mathbb{D}}$ and Florent Allais * $\mathbb{D}$ \\ URD Agro-Biotechnologies Industrielles (ABI), CEBB, AgroParisTech, 51110 Pomacle, France; \\ cedric.peyrot@agroparistech.fr (C.P.); matthieu.mention@agroparistech.fr (M.M.M.); \\ fanny.brunissen@agroparistech.fr (F.B.) \\ * Correspondence: florent.allais@agroparistech.fr; Tel.: +33-352-620-462 \\ + These authors contributed equally to this work.
}

Received: 11 August 2020; Accepted: 21 August 2020; Published: 24 August 2020

\begin{abstract}
In 2021, Hawaii will permanently ban the use and sale of octinoxate-based sunscreens as studies have shown serious impacts of such UV filters on the coral reef. This ban, which could be generalized to other countries, highlights the extreme need to offer alternative UV filters that are not only effective in terms of sun protection, but also healthy with regards to human health and the environment. In this context, a wide library of $p$-hydroxycinnamic esters deriving from naturally occurring sinapic acid has been synthesized using a Knoevenagel-Doebner condensation. The UV filtering activities as well as the antioxidant properties of these sinapic acid esters were then investigated. The results showed promising UVB protection and antioxidant efficacy. A Structure-Activity Relationship (SAR) study on the sinapic acid esters highlighted the need of a free phenol to, as expected, observe antioxidant activity, but also to obtain a higher intensity of protection. Moreover, the nature of the ester moiety also proved to be a key structural feature for the UV absorbance, as higher steric hindrance on the ester moiety leads to more active compounds. The judicious structural design of sinapic esters thus provides promising compounds combining UV protection and antioxidant activity.
\end{abstract}

Keywords: organic UV filters; antioxidant; sinapic acid esters; photoprotection; bio-based chemicals

\section{Introduction}

A high level of sun exposure can lead to sunburn, premature skin aging and, in the worst case, severe forms of skin cancer [1-3]. To offset those negative effects, the use of UV protection is essential. There are two types of commonly used UV filters: mineral filters $\left(\mathrm{TiO}_{2}, \mathrm{ZnO}\right)$ and organic filters (avobenzone, octocrylene or octinoxate) [4,5]. The latter is a UVB filter commonly found in sunscreen lotions used on beaches worldwide. However, in recent years, octinoxate has been strongly criticized, in particular for its negative impact on the environment but also on human health $[6,7]$. Indeed, several studies have demonstrated that organic UV filters induce a virus proliferation which is the source of coral reef bleaching [8,9]. To protect its coral reefs, Hawaii has notably banned the use and sale of sunscreen products containing octinoxate on its territory, starting January 2021 [10]. Such a drastic decision could be taken by many other states in the coming years. Moreover, octinoxate is actively challenged for its endocrine disrupting activity, which can have serious effects on humans [11]. Considering the above considerations, designing new safer alternatives to current UVB filters remains a challenge.

From a synthetic point of view, octinoxate also presents many disadvantages. Indeed, this molecule, produced on a very large scale, is obtained from non-renewable fossil resources. Several patents and 
publications offer various synthetic routes [12-15]; the one mainly used at the industrial scale starts with 4-bromo-anisole and consists of reacting it with 2-ethylhexyl acrylate via a palladium-catalyzed Heck reaction in aprotic polar solvent (NMP, DMF) (yields > 80\%) [16,17]. Several optimizations have been proposed, notably the use of reusable ionic liquids as a solvent [18]. Other alternatives starting from renewable resources have been proposed. For instance, $p$-coumaric acid, one of the major lignocellulosic-derived $p$-hydroxycinnamic acids [19], is subjected to methylation then esterification with 2-ethylhexanol $[20,21]$. It is noteworthy that the esterification can be carried out either chemically or enzymatically with lipases [22,23]. The most-described chemical pathway relies on the formation of the acyl chloride and the subsequent reaction with 2-ethylhexanol [24]. Transesterification of 4-methoxy-ethylcinnamate is also reported in the literature [20,25].

Through the same synthetic pathway, octinoxate analogues were synthesized from ferulic acid [24] and caffeic acid [24], two other naturally occurring $p$-hydroxycinnamic acids. Nevertheless, to the best of our knowledge, no sinapic acid-based analogue has ever been described (Figure 1). This is particularly surprising as it is well known that sinapic acid is the most efficient in terms of absorbance among p-hydroxycinnamic acids.

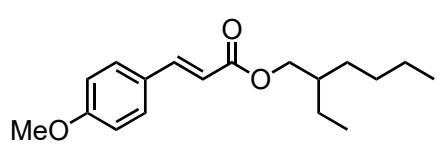

Octinoxate

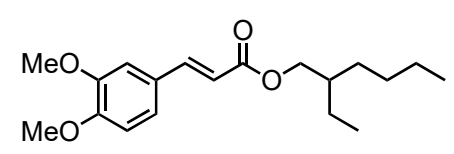

Ferulic/caffeic acid analogue

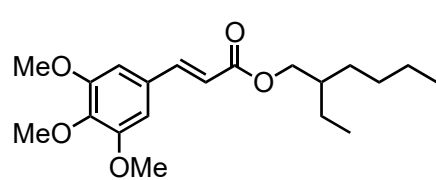

Sinapic acid analogue

Figure 1. Octinoxate and analogues.

In addition, sinapic acid has already demonstrated its great potential as a starting material for UV filter production [26,27]. Moreover, naturally occurring sinapoyl malate plays the role of a UV filter at the leaves' surface to protect them from the harmful effects of UV radiation [28]. Several physico-chemical studies have made it possible to better understand the protection mechanism of those molecules $[29,30]$. Recent work on the highly selective $\beta-\beta$ dimerization of sinapic acid esters has highlighted their great potential both as UV filters and antioxidants [26]. Based on these observations, we decided to focus our efforts on the synthesis of renewable sinapic-acid-based octinoxate analogues with dual properties (i.e., UV filter, antioxidant). After having constituted a library of analogues using the well-described pyridine/aniline-mediated Knoevenagel-Doebner condensation as a key step, the influence of the phenol methylation, as well as that of the nature of the ester moiety, on the UV absorbance properties and the antioxidant activity, has been investigated using SARs. Photostability upon UV irradiation was also assessed.

\section{Materials and Methods}

\subsection{Chemical Synthesis}

Syringaldehyde, aniline, pyridine, heptan-1-ol, oleic alcohol, 3,5-dimethylphenol, $o$-cresol, solketal, eugenol, Meldrum's acid and DPPH were purchased from Sigma Aldrich (St. Louis, MO, USA). Thymol, $p$-hydroxybenzaldehyde, 2-ethylhexan-1-ol, guaiacol and $n$-butylamine were purchased from TCI (Tokyo, Japan). Conc. $\mathrm{HCl}$ and solvents were purchased from Fisher Scientific (Hampton, NH, USA) and used as received. All chemicals were used directly without purification.

Chromatographic purifications of products were accomplished using a flash-prep LC system puriFlash ${ }^{\circledR} 4100$ from Interchim (Montluçon, France) with prepacked silica column (30 $\mu$ m, Interchim PF-Si30-HP), dual wavelength collection $(\lambda=254 / 320 \mathrm{~nm})$ in cyclohexane/ethyl acetate eluent. ${ }^{1} \mathrm{H}$ NMR spectra were recorded on a Bruker Fourier 300 (300 MHz) (Bruker, Billerica, MA, USA) and were calibrated with residual DMSO- $d_{6}$ or $\mathrm{CDCl}_{3}$ protons signals at $\delta 2.50$ or $7.26 \mathrm{ppm}$, respectively. Data are reported as follows: chemical shift $(\delta \mathrm{ppm})$, multiplicity $(\mathrm{s}=$ singlet, $\mathrm{d}=$ doublet, $\mathrm{t}=$ triplet, $\mathrm{q}$ $=$ quartet, sept $=$ septet, $\mathrm{dd}=$ doublet of doublet, $\mathrm{td}=$ triplet of doublet, $\mathrm{m}=$ multiplet $)$, coupling 
constant (Hz), integration and assignment. ${ }^{13} \mathrm{C}$ NMR spectra were recorded on a Bruker Fourier 300 (75 MHz) (Bruker, Billerica, MA, USA) and were calibrated with DMSO- $d_{6}$ or $\mathrm{CDCl}_{3}$ signal at $\delta 39.52$ or $77.16 \mathrm{ppm}$, respectively. Data are reported as follows: chemical shift $(\delta \mathrm{ppm})$ and attribution. ${ }^{1} \mathrm{H}$ and ${ }^{13} \mathrm{C}$ NMR spectra are available in the ESI. All NMR assignments were made using COSY, HMBC and HSQC spectra. IR spectra were recorded on an Agilent Cary 630 FTIR Spectrometer (Wilmington, DE, USA) and are reported by frequency of absorption $\left(\mathrm{cm}^{-1}\right)$. Melting points were recorded on a Mettler Toledo MP50 Melting Point System (Greifensee, Switzerland) with ME-18552 sample tubes. HRMS were performed on an Agilent 1290 system (Wilmington, DE, USA), equipped with a PDA UV detector, and a $6545 \mathrm{Q}$-TOF mass spectrometer with a JetStream ESI probe operating at atmospheric pressure as the source.

\subsubsection{Malonate Mono-Esters General Procedures}

General Procedure 1 (GP1): Meldrum's acid (5.0 g, $35 \mathrm{mmol})$ and the corresponding alcohol ( $35 \mathrm{mmol}, 1 \mathrm{eq}$ ) were melted at $95^{\circ} \mathrm{C}$ and stirred for $3 \mathrm{~h}$. After cooling at r.t., the reaction mixture was partitioned between ethyl acetate and saturated aq. $\mathrm{NaHCO}_{3}$. The aqueous layer was acidified until $\mathrm{pH}=1$ with concentrated $\mathrm{HCl}$ and extracted with ethyl acetate. The resulting organic layer was dried over anhydrous $\mathrm{MgSO}_{4}$, filtered and concentrated.

General Procedure 2 (GP2): Meldrum's acid $(4.0 \mathrm{~g}, 27.8 \mathrm{mmol})$ and an excess of the corresponding alcohol were heated at reflux overnight. After cooling at r.t., the excess of alcohol was evaporated under reduced pressure.

For each intermediate, yields, NMR analyses and spectra are available in the supplementary information.

\subsubsection{Sinapate Esters}

The corresponding malonate mono-ester $(8.6 \mathrm{mmol}), p$-hydroxybenzaldehyde or syringaldehyde ( $10.4 \mathrm{mmol}, 1.2 \mathrm{eq})$ and aniline $(79 \mu \mathrm{L}, 0.86 \mathrm{mmol})$ were mixed in pyridine $(5.7 \mathrm{~mL})$. The reaction mixture was stirred at $60^{\circ} \mathrm{C}$ overnight. After cooling at r.t., the reaction was partitioned between ethyl acetate and $1 \mathrm{M}$ aqueous $\mathrm{HCl}$. The organic layer was dried over anhydrous $\mathrm{MgSO}_{4}$, filtered and concentrated before being purified by flash chromatography using cyclohexane/ethyl acetate.

2-Ethylhexyl sinapate (1) was synthesized as a yellow oil (66\% yield) from syringaldehyde and corresponding malonic monoester. Characterization data were identical to those already described. $\lambda_{\max }(\mathrm{EtOH}, \mathrm{nm}) 332 . \varepsilon\left(\mathrm{L} \cdot \mathrm{mol}^{-1} \cdot \mathrm{cm}^{-1}\right): 19643$ [26].

Ethyl sinapate (4) was synthesized following procedure from Jaufurally et al. Characterization data were identical to those already described in the literature. $\lambda_{\max }(\mathrm{EtOH}, \mathrm{nm}) 328 . \varepsilon\left(\mathrm{L} \cdot \mathrm{mol}^{-1} \cdot \mathrm{cm}^{-1}\right)$ : 15015 [31].

tert-Butyl sinapate (5) was synthesized as a pale-yellow powder (60\% yield) from syringaldehyde and corresponding malonic monoester. Characterization data were identical to those already described in the literature. $\lambda_{\max }(\mathrm{EtOH}, \mathrm{nm}) 327 . \varepsilon\left(\mathrm{L} \cdot \mathrm{mol}^{-1} \cdot \mathrm{cm}^{-1}\right): 20847$ [26].

Oleyl sinapate (6) was synthesized as an orange oil (44\% yield) from syringaldehyde and corresponding malonic monoester. ${ }^{1} \mathbf{H}$ NMR $\left(300 \mathrm{MHz}, \mathrm{DMSO}-d_{6}\right): \delta(\mathrm{ppm}) 8.97(\mathrm{~s}, 1 \mathrm{H}, \mathrm{OH}), 7.54$ $(\mathrm{d}, J=15.9 \mathrm{~Hz}, 1 \mathrm{H}, \mathrm{H} 3), 7.02(\mathrm{~s}, 2 \mathrm{H}, \mathrm{H} 5), 6.52(\mathrm{~d}, J=15.9 \mathrm{~Hz}, 1 \mathrm{H}, \mathrm{H} 2), 5.32(\mathrm{t}, J=5.0 \mathrm{~Hz}, 2 \mathrm{H}, \mathrm{H} 17+$ $\mathrm{H} 18), 4.11(\mathrm{t}, J=6.5 \mathrm{~Hz}, 2 \mathrm{H}, \mathrm{H} 9), 3.79(\mathrm{~s}, 6 \mathrm{H}, \mathrm{H} 8), 1.98(\mathrm{~m}, 4 \mathrm{H}, \mathrm{H} 16+\mathrm{H} 19), 1.60$ (m, 2H, H10), 1.25 (m, 22H, H11-15 + H20-25), $0.84(\mathrm{~m}, 3 \mathrm{H}, \mathrm{H} 26) .{ }^{13} \mathrm{C}$ NMR (75 MHz, DMSO-d $\left.d_{6}\right): \delta$ (ppm) 167.1 (C1), 148.5 (C6), 145.7 (C3), 138.7 (C7), 130.1 (C17 + C18), 124.8 (C4), 115.4 (C2), 106.6 (C5), 64.2 (C9), 56.5 (C8), 31.8 (C11-15 or C20-25), 29.0-29.6 (C11-15 or C20-25), 28.8 (C10), 27.0 (C16 + C19), 22.6 (C11-15 or C20-25), $14.4(\mathrm{C} 26) \cdot \lambda_{\max }(\mathrm{EtOH}, \mathrm{nm}) 331 . \varepsilon\left(\mathrm{L} \cdot \mathrm{mol}^{-1} \cdot \mathrm{cm}^{-1}\right): 16,767$. HRMS $(\mathrm{m} / z)[\mathrm{M}+\mathrm{H}]^{+}$calcd for $\mathrm{C}_{29} \mathrm{H}_{47} \mathrm{O}_{5}$ : 475.3423; found: 475.3417 .

iso-Propyl sinapate (7) was synthesized as a pale-yellow oil (73\% yield) from syringaldehyde and corresponding malonic monoester. Characterization data were identical to those already described in the literature. $\lambda_{\max }(\mathrm{EtOH}, \mathrm{nm}) 330 . \varepsilon\left(\mathrm{L} \cdot \mathrm{mol}^{-1} \cdot \mathrm{cm}^{-1}\right): 19584$ [32]. 
Solketal sinapate (8) was synthesized as an orange powder (57\% yield) from syringaldehyde and corresponding malonic monoester. ${ }^{1} \mathrm{H}$ NMR $\left(300 \mathrm{MHz}, \mathrm{CDCl}_{3}\right): \delta(\mathrm{ppm}) 7.62(\mathrm{~d}, J=15.8 \mathrm{~Hz}, 1 \mathrm{H}, \mathrm{H} 3)$, 6.76 (s, 2H, H5), 6.35 (d, J = 15.8 Hz, 2H, H2), 4.40 (m, 1H, H10), 4.32 (dd, J = 11.5, 4.41 Hz, 1H, H9), 4.18 $(\mathrm{dd}, J=11.5,6.3 \mathrm{~Hz}, 1 \mathrm{H}, \mathrm{H} 9), 4.13(\mathrm{dd}, J=8.3,6.4 \mathrm{~Hz}, 1 \mathrm{H}, \mathrm{H} 11), 3.91$ (s, 6H, H8) $3.80(\mathrm{dd}, J=8.4,6.0 \mathrm{~Hz}$, 1H, H11), 1.46 (s, 3H, H13 or H14), 1.39 (s, 3H, H13 or H14). ${ }^{13}$ C NMR $\left(75 \mathrm{MHz}, \mathrm{CDCl}_{3}\right): \delta$ (ppm) 167.0 (C1), 147.3 (C6), 145.9 (C3), 137.3 (C7), 125.9 (C4) 115.3 (C2), 110.1 (C12), 105.2 (C5), 73.9 (C10), 66.5 (C11), 65.0 (C9), 56.4 (C8), 29.9 (C13 or C14), 25.5 (C13 or C14). $\lambda_{\max }(\mathrm{EtOH}, \mathrm{nm}) 332 . \varepsilon\left(\mathrm{L} \cdot \mathrm{mol}^{-1} \cdot \mathrm{cm}^{-1}\right)$ : 15460. Mp: $104-106^{\circ} \mathrm{C}$. HRMS $(m / z)[\mathrm{M}+\mathrm{H}]^{+}$calcd for $\mathrm{C}_{17} \mathrm{H}_{23} \mathrm{O}_{7}$ : 339.1444; found: 339.1452.

Heptyl sinapate (9) was synthesized as a brown oil (72\% yield) from syringaldehyde and corresponding malonic monoester. Characterization data were identical to those already described in the literature. $\lambda_{\max }(\mathrm{EtOH}, \mathrm{nm}) 330 . \varepsilon\left(\mathrm{L} \cdot \mathrm{mol}^{-1} \cdot \mathrm{cm}^{-1}\right): 19009$ [26].

Syringol sinapate (10) was synthesized as a white powder (39\% yield) from syringaldehyde and corresponding malonic monoester. ${ }^{1} \mathbf{H}$ NMR (300 MHz, DMSO- $\left.d_{6}\right): \delta$ (ppm) 9.09 (s, 1H, OH), 7.70 $(\mathrm{d}, J=15.9 \mathrm{~Hz}, 1 \mathrm{H}, \mathrm{H} 3), 7.18(\mathrm{t}, J=9.0 \mathrm{~Hz}, 1 \mathrm{H}, \mathrm{H} 12), 7.13$ (s, 2H, H5), 6.78 (d, J = 15.9 Hz, 1H, H2), $6.76(\mathrm{~d}, J=9.0 \mathrm{~Hz}, 2 \mathrm{H}, \mathrm{H} 11), 3.81(\mathrm{~s}, 6 \mathrm{H}, \mathrm{H} 8), 3.75(\mathrm{~s}, 6 \mathrm{H}, \mathrm{H} 13) .{ }^{13} \mathrm{C}$ NMR $\left(75 \mathrm{MHz}, \mathrm{DMSO}-d_{6}\right): \delta$ (ppm) 164.4 (C1), 152.2 (C10), 148.1 (C6), 147.2 (C3), 138.7 (C7), 128.2 (C9), 126.2 (C12), 124.3 (C4), 113.8 (C2), 106.6 (C5), 105.0 (C11), 56.1 (C8), 56.0 (C13). $\lambda_{\max }(\mathrm{EtOH}, \mathrm{nm}) 334 . \varepsilon\left(\mathrm{L} \cdot \mathrm{mol}^{-1} \cdot \mathrm{cm}^{-1}\right): 21,458 . ~ M p:$ 169-172 ${ }^{\circ} \mathrm{C}$. HRMS $(\mathrm{m} / \mathrm{z})[\mathrm{M}+\mathrm{Na}]^{+}$calcd for $\mathrm{C}_{19} \mathrm{H}_{20} \mathrm{O}_{7} \mathrm{Na}: 383.1107$; found: 383.1110 .

Guaiacol sinapate (11) was synthesized as a yellow-orange powder (55\% yield) from syringaldehyde and corresponding malonic monoester. Characterization data were identical to those already described in the literature. $\lambda_{\max }(\mathrm{EtOH}, \mathrm{nm}) 337 . \varepsilon\left(\mathrm{L}_{\mathrm{mol}}^{-1} \cdot \mathrm{cm}^{-1}\right): 25135[26]$.

Cresol sinapate (12) was synthesized as yellow powder (63\% yield) from syringaldehyde and the corresponding malonic monoester. ${ }^{1} \mathbf{H}$ NMR $\left(300 \mathrm{MHz}, \mathrm{DMSO}-d_{6}\right): \delta(\mathrm{ppm}) 9.10(\mathrm{~s}, 1 \mathrm{H}, \mathrm{OH}), 7.78$ $(\mathrm{d}, J=15.9 \mathrm{~Hz}, 1 \mathrm{H}, \mathrm{H} 3), 7.31$ (td, $J=7.2,1.5 \mathrm{~Hz}, 1 \mathrm{H}, \mathrm{H} 13), 7.25$ (dd, J = 7.6, 1.7 Hz, 1H, H11), 7.20 (dd, $=7.3,1.5 \mathrm{~Hz}, 1 \mathrm{H}, \mathrm{H} 14), 7.14(\mathrm{~s}, 2 \mathrm{H}, \mathrm{H} 5), 7.10(\mathrm{dd}, J=7.7,1.4 \mathrm{~Hz}, 1 \mathrm{H}, \mathrm{H} 12), 6.81(\mathrm{~d}, J=15.9 \mathrm{~Hz}, 1 \mathrm{H}, \mathrm{H} 2)$, 3.82 (s, 6H, H8), 2.14 (s, 3H, H15). ${ }^{13} \mathrm{C}$ NMR (75 MHz, DMSO-d 6 ): $\delta$ (ppm) 165.1 (C1), 149.3 (C9), 148.1 (C6), 147.5 (C3), 138.8 (C7), 131.0 (C13), 130.0 (C10), 127.1 (C11), 125.9 (C14), 124.2 (C4), 122.2 (C12), $113.6(\mathrm{C} 2), 106.6$ (C5), $56.1(\mathrm{C} 8), 15.9$ (C15). $\lambda_{\max }(\mathrm{EtOH}, \mathrm{nm}) 338 . \varepsilon\left(\mathrm{L}^{\mathrm{mol}}{ }^{-1} \cdot \mathrm{cm}^{-1}\right): 31314 \mathrm{~cm}^{-1} . \mathrm{Mp}$ 120-122 ${ }^{\circ} \mathrm{C}$. HRMS $(\mathrm{m} / \mathrm{z})[\mathrm{M}+\mathrm{H}]^{+}$calcd for $\mathrm{C}_{18} \mathrm{H}_{19} \mathrm{O}_{5}: 315.1232$; found: 315.1230 .

Thymol sinapate (13) was synthesized as a white powder (73\% yield) from syringaldehyde and corresponding malonic monoester. ${ }^{1} \mathrm{H}$ NMR $\left(300 \mathrm{MHz}, \mathrm{DMSO}-d_{6}\right): \delta(\mathrm{ppm}) 9.09(\mathrm{~s}, 1 \mathrm{H}, \mathrm{OH}), 7.76(\mathrm{~d}, J$ $=15.9 \mathrm{~Hz}, 1 \mathrm{H}, \mathrm{H} 3), 7.26(\mathrm{~d}, J=7.9 \mathrm{~Hz}, 1 \mathrm{H}, \mathrm{H} 14), 7.14(\mathrm{~s}, 2 \mathrm{H}, \mathrm{H} 5), 7.06(\mathrm{dd}, J=7.9,1.1 \mathrm{~Hz}, 1 \mathrm{H}, \mathrm{H} 13), 6.88$ $(\mathrm{d}, J=1.0 \mathrm{~Hz}, 1 \mathrm{H}, \mathrm{H} 11), 6.82(\mathrm{~d}, J=15.9 \mathrm{~Hz}, 1 \mathrm{H}, \mathrm{H} 2), 3.82$ (s, 6H, H8), 2.94 (sept, $J=7.0 \mathrm{~Hz}, 1 \mathrm{H}, \mathrm{H} 15)$, $2.28(\mathrm{~s}, 3 \mathrm{H}, \mathrm{H} 17), 1.14(\mathrm{~d}, J=6.9 \mathrm{~Hz}, 6 \mathrm{H}, \mathrm{H} 16) .{ }^{13} \mathrm{C}$ NMR $\left(75 \mathrm{MHz}, \mathrm{DMSO}-d_{6}\right): \delta(\mathrm{ppm}) 166.1(\mathrm{C} 1)$, 148.5 (C6), 148.2 (C9), 147.8 (C3), 139.4 (C7), 137.3 (C10), 136.6 (C12), 127.3 (C13), 126.8 (C14), 124.6 (C4), 123.3 (C11), 114.1 (C2), 107.1 (C5), 56.6 (C8), 27.1 (C15), 23.4 (C16), 20.8 (C17). $\lambda_{\max }(\mathrm{EtOH}, \mathrm{nm}) 337 . \varepsilon$ $\left(\mathrm{L} \cdot \mathrm{mol}^{-1} \cdot \mathrm{cm}^{-1}\right): 27330$. Mp: $120-122{ }^{\circ} \mathrm{C}$. HRMS $(\mathrm{m} / \mathrm{z})[\mathrm{M}+\mathrm{H}]^{+}$calcd for $\mathrm{C}_{21} \mathrm{H}_{25} \mathrm{O}_{5}$ : 357.1702; found: 357.1701.

Eugenol sinapate (14) was synthesized as a yellow powder (48\% yield) from syringaldehyde and corresponding malonic monoester. ${ }^{1} \mathrm{H}$ NMR $\left(300 \mathrm{MHz}, \mathrm{DMSO}-d_{6}\right): \delta(\mathrm{ppm}) 9.07(\mathrm{~s}, 1 \mathrm{H}, \mathrm{OH}), 7.71(\mathrm{~d}, J$ $=15.8 \mathrm{~Hz}, 1 \mathrm{H}, \mathrm{H} 3), 7.12(\mathrm{~s}, 2 \mathrm{H}, \mathrm{H} 5), 7.04(\mathrm{~d}, J=8.0 \mathrm{~Hz}, 1 \mathrm{H}, \mathrm{H} 14), 6.96(\mathrm{~d}, J=1.2 \mathrm{~Hz}, 1 \mathrm{H}, \mathrm{H} 13), 6.78$ (d, J $=6.8 \mathrm{~Hz}, 1 \mathrm{H}, \mathrm{H} 14), 6.76(\mathrm{~d}, J=15.9 \mathrm{~Hz}, 1 \mathrm{H}, \mathrm{H} 2), 5.99(\mathrm{~m}, 1 \mathrm{H}, \mathrm{H} 16), 5.12(\mathrm{dd}, J=21.0,1.5 \mathrm{~Hz}, 1 \mathrm{H}, \mathrm{H} 17)$, $5.07(\mathrm{~d}, J=10.2 \mathrm{~Hz}, 1 \mathrm{H}, \mathrm{H} 17), 3.81$ (s, 6H, H8), 3.74 (s, 3H, H18), 3.38 (d, J = 6.8 Hz, 2H, H15). ${ }^{13} \mathrm{C}$ NMR $\left(75 \mathrm{MHz}, \mathrm{DMSO}-d_{6}\right): \delta(\mathrm{ppm})=164.9(\mathrm{C} 1), 150.9(\mathrm{C} 10), 148.1$ (C6), $147.2(\mathrm{C} 3), 138.7$ (C9 or C12), 138.7 (C9 or C12), 137.7 (C7), 137.5 (C16), 124.3 (C4), 122.8 (C14), 120.3 (C13), 116.1 (C17), 113.8 (C2), 112.9 (C11), 106.6 (C5), 56.1 (C8), 55.7 (C18), 39.4 (C15). $\lambda_{\max }(\mathrm{EtOH}, \mathrm{nm}) 337 . \varepsilon\left(\mathrm{L}_{\mathrm{mol}} \mathrm{m}^{-1} \cdot \mathrm{cm}^{-1}\right): 25991$. Mp: $140-142{ }^{\circ} \mathrm{C}$. HRMS $(\mathrm{m} / \mathrm{z})[\mathrm{M}+\mathrm{H}]^{+}$calcd for $\mathrm{C}_{21} \mathrm{H}_{23} \mathrm{O}_{6}$ : 371.1495; found: 371.1491 . 


\subsubsection{Methylation of (4)}

2-Ethylhexyl sinapate (1) (212 mg, $0.63 \mathrm{mmol}, 0.5 \mathrm{M}$ ) was dissolved in anhydrous DMF (1.2 mL) and placed under $\mathrm{N}_{2}$. After $10 \mathrm{~min}$ of stirring, $\mathrm{K}_{2} \mathrm{CO}_{3}(248 \mathrm{mg}, 1.79 \mathrm{mmol}, 3 \mathrm{eq})$ and methyl iodide ( $45 \mu \mathrm{L}, 0.71 \mathrm{mmol}, 1.2 \mathrm{eq}$ ) were added and the reaction was stirred overnight under $\mathrm{N}_{2}$ at r.t. The mixture was then diluted in $1 \mathrm{M}$ aqueous $\mathrm{HCl}$ and partitioned between ethyl acetate and $\mathrm{H}_{2} \mathrm{O}$. The organic layer was dried over anhydrous $\mathrm{MgSO}_{4}$, filtered and concentrated to afford methylated 2-ethylhexyl sinapate (2) as a yellow oil (89\% yield). ${ }^{1} \mathrm{H}$ NMR (300 MHz, DMSO- $\left.d_{6}\right): \delta(\mathrm{ppm}) 7.58(\mathrm{~d}, J=16.0 \mathrm{~Hz}$, 1H, H3), 7.08 (s, 2H, H5), 6.66 (d, J = 16.0 Hz, 1H, H2), 4.07 (dd, J = 5.7, $2.2 \mathrm{~Hz}, 2 \mathrm{H}, \mathrm{H} 10), 3.82$ (s, 6H, H8), 3.68 (s, 3H, H9), 1.61 (m, 1H, H11), 1.29 (m, 8H, H12 + H13 + H14 + H16), 0.88 (m, 6H, H15 + H17). ${ }^{13} \mathrm{C}$ NMR (75 MHz, DMSO- $\left.d_{6}\right): \delta$ (ppm) 166.6 (C1), 153.1 (C6), 144.7 (C3), 139.4 (C7), 129.6 (C4), 117.4 (C2), 106.0 (C5), 66.0 (C10), 60.1 (C9), 56.1 (C8), 38.3 (C11), 29.8 (C12), 28.4 (C13), 23.2 (C16), 22.5 (C14), $14.0(\mathrm{C} 15), 10.8(\mathrm{C} 17) . \lambda_{\max }(\mathrm{EtOH}, \mathrm{nm}) 308 . \varepsilon\left(\mathrm{L}^{2} \mathrm{~mol}^{-1} \cdot \mathrm{cm}^{-1}\right): 14173$. HRMS $(\mathrm{m} / \mathrm{z})[\mathrm{M}+\mathrm{H}]^{+}$ calcd for $\mathrm{C}_{20} \mathrm{H}_{31} \mathrm{O}_{5}$ : 351.2171; found: 351.2172 .

\subsubsection{Acetylation of (4)}

2-Ethyhexyl sinapate (1) $(202 \mathrm{mg}, 0.60 \mathrm{mmol}, 1 \mathrm{M})$ was dissolved in acetic anhydride ( $300 \mu \mathrm{L}$, $2.97 \mathrm{mmol}, 5 \mathrm{eq})$ and pyridine $(600 \mu \mathrm{L}, 7.5 \mathrm{mmol})$ and stirred at r.t. overnight. The mixture was then diluted in $1 \mathrm{M}$ aqueous $\mathrm{HCl}$ and partitioned between ethyl acetate and $\mathrm{H}_{2} \mathrm{O}$. The organic layer was dried over anhydrous $\mathrm{MgSO}_{4}$, filtered and concentrated to afford acetylated 2-ethylhexyl sinapate (3) as a pale-yellow oil (83\% yield). ${ }^{1} \mathbf{H}$ NMR $\left(300 \mathrm{MHz}, \mathrm{DMSO}-d_{6}\right): \delta(\mathrm{ppm}) 7.61(\mathrm{~d}, J=16.0 \mathrm{~Hz}, 1 \mathrm{H}, \mathrm{H} 3)$, $7.16(\mathrm{~s}, 2 \mathrm{H}, \mathrm{H} 5), 6.76$ (d, J = 16.0 Hz, 1H, H2), 4.08 (dd, J = 5.7, $2.3 \mathrm{~Hz}, 2 \mathrm{H}, \mathrm{H} 11), 3.80$ (s, 6H, H8), 2.25 (m, 3H, H10), $1.61(\mathrm{~m}, 1 \mathrm{H}, \mathrm{H} 12), 1.29(\mathrm{~m}, 8 \mathrm{H}, \mathrm{H} 13+\mathrm{H} 14+\mathrm{H} 15+\mathrm{H} 17), 0.87(\mathrm{~m}, 6 \mathrm{H}, \mathrm{H} 16+\mathrm{H} 18) .{ }^{13} \mathrm{C}$ NMR (75 MHz, DMSO- $d_{6}$ ): 168.0 (C9), 166.4 (C1), 152.0 (C6), 144.4 (C3), 132.5 (C7), 132.0 (C4), 118.6 (C2), 105.4 (C5), 66.0 (C11), 56.2 (C8), 39.3 (C12), 29.8 (C13), 28.4 (C14), 23.2 (C17), 22.5 (C15), 20.2 (C10),

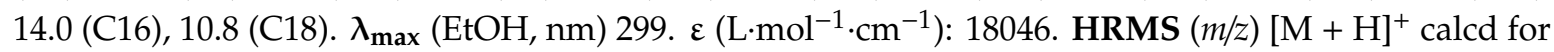
$\mathrm{C}_{21} \mathrm{H}_{31} \mathrm{O}_{6}$ : 379.2121; found: 379.2120 .

\subsubsection{Amide Derivatives}

Meldrum's acid ( $1.44 \mathrm{~g}, 10 \mathrm{mmol}, 0.2 \mathrm{M})$ and the corresponding amine $(10 \mathrm{mmol}, 1 \mathrm{eq})$ were mixed in acetonitrile $(50 \mathrm{~mL})$, the resulting mixture was heated at $60^{\circ} \mathrm{C}$ for $4 \mathrm{~h}$. After cooling at r.t., acetonitrile was evaporated under vacuum to afford the corresponding intermediary. The crude product was used without purification, mixed with syringaldehyde ( $12 \mathrm{mmol}, 1.2 \mathrm{eq})$, aniline (1.2 mmol, $0.1 \mathrm{eq})$ and dissolved in pyridine $(6.7 \mathrm{~mL})$. The mixture was heated at $60^{\circ} \mathrm{C}$ overnight. After cooling at r.t. the reaction was partitioned between $\mathrm{AcOEt}$ and $1 \mathrm{M}$ aqueous $\mathrm{HCl}$. The organic layer was dried over anhydrous $\mathrm{MgSO}_{4}$, filtered and concentrated prior to purification by flash chromatography using cyclohexane/AcOEt as eluant.

$\mathrm{N}$-phenyl sinapoylamide (15) was synthesized as a yellow powder $\left(25 \%\right.$ yield) using aniline. ${ }^{\mathbf{1}} \mathbf{H}$ NMR (300 MHz, DMSO- $\left.d_{6}\right): \delta(\mathrm{ppm}) 10.10(\mathrm{~s}, 1 \mathrm{H}, \mathrm{NH}), 8.91(\mathrm{~s}, 1 \mathrm{H}, \mathrm{OH}), 7.69(\mathrm{~d}, J=7.6 \mathrm{~Hz}, 2 \mathrm{H}, \mathrm{H} 10)$, $7.50(\mathrm{~d}, J=15.6 \mathrm{~Hz}, 1 \mathrm{H}, \mathrm{H} 3), 7.32(\mathrm{t}, J=7.9 \mathrm{~Hz}, 2 \mathrm{H}, \mathrm{H} 11), 7.04(\mathrm{t}, J=7.4 \mathrm{~Hz}, 1 \mathrm{H}, \mathrm{H} 12), 6.92(\mathrm{~s}, 2 \mathrm{H}, \mathrm{H} 5)$, $6.67(\mathrm{~d}, J=15.6 \mathrm{~Hz}, 1 \mathrm{H}, \mathrm{H} 2), 3.82(\mathrm{~s}, 6 \mathrm{H}, \mathrm{H} 8) .{ }^{13} \mathrm{C}$ NMR $\left(75 \mathrm{MHz}, \mathrm{DMSO}-d_{6}\right): \delta(\mathrm{ppm}) 164.0(\mathrm{C} 1), 148.1$ (C6), 141.0 (C3), 139.6 (C9), 137.7 (C7), 128.8 (C11), 125.1 (C4), 123.2 (C12), 119.3 (C2), 119.1 (C10), 105.4 (C5), $56.0(\mathrm{C} 8) \cdot \lambda_{\max }(\mathrm{EtOH}, \mathrm{nm}) 336 \cdot \varepsilon\left(\mathrm{L} \cdot \mathrm{mol}^{-1} \cdot \mathrm{cm}^{-1}\right): 25757 . \mathbf{M p}: 74-77^{\circ} \mathrm{C} . \mathbf{H R M S}(\mathrm{m} / \mathrm{z})[\mathrm{M}+\mathrm{H}]^{+}$ calcd for $\mathrm{C}_{17} \mathrm{H}_{18} \mathrm{NO}_{4}$ : 300.1236; found: 300.1235 .

$N$-butyl sinapoylamide (16) was synthesized as a yellow powder (13\% yield) using $n$-butylamine. ${ }^{1}$ H NMR (300 MHz, DMSO- $\left.d_{6}\right): \delta(\mathrm{ppm}) 8.78(\mathrm{~s}, 1 \mathrm{H}, \mathrm{OH}), 7.92(\mathrm{t}, J=5.6 \mathrm{~Hz}, 1 \mathrm{H}, \mathrm{NH}), 7.30(\mathrm{~d}, J=$ $15.7 \mathrm{~Hz}, 1 \mathrm{H}, \mathrm{H} 3), 6.84(\mathrm{~s}, 2 \mathrm{H}, \mathrm{H} 5), 6.46(\mathrm{~d}, J=15.7 \mathrm{~Hz}, 1 \mathrm{H}, \mathrm{H} 2), 3.79(\mathrm{~s}, 6 \mathrm{H}, \mathrm{H} 8), 3.15(\mathrm{q}, J=6.7 \mathrm{~Hz}, 2 \mathrm{H}$, H9), 1.40 (m, 2H, H10), 1.30 (m, 2H, H11), 0.88 (t, $J=7.2 \mathrm{~Hz}, 3 \mathrm{H}, \mathrm{H} 12) .{ }^{13} \mathrm{C}$ NMR $\left(75 \mathrm{MHz}, \mathrm{DMSO}-d_{6}\right)$ : $\delta$ (ppm) 165.2 (C1), 148.1 (C6), 141.0 (C3), 139.6 (C9), 137.7 (C7), 128.8 (C11), 125.1 (C4), 123.2 (C12), 


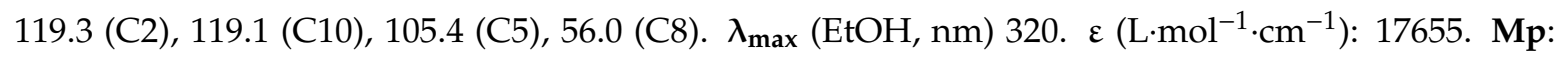
104-106 ${ }^{\circ} \mathrm{C}$. HRMS $(\mathrm{m} / \mathrm{z})[\mathrm{M}+\mathrm{H}]^{+}$calcd for $\mathrm{C}_{15} \mathrm{H}_{22} \mathrm{NO}_{4}$ : 280.1549; found: 280.1550 .

\subsubsection{Ketone Derivative}

Syringaldehyde $(1 \mathrm{~g}, 5.5 \mathrm{mmol})$ was dissolved in acetone $(50 \mathrm{~mL})$ and placed in an ice bath. A solution of $\mathrm{NaOH}(3.5 \mathrm{~g}, 87.5 \mathrm{mmol})$ in $\mathrm{H}_{2} \mathrm{O}(35 \mathrm{~mL})$ was added dropwise. After complete addition, the reaction mixture was stirred until it reached room temperature. Excess of $\mathrm{NaOH}$ was neutralized with aqueous $1 \mathrm{M} \mathrm{HCl}$ and the mixture was extracted with ethyl acetate. The organic layer was dried over anhydrous $\mathrm{MgSO} 4$, filtered and evaporated under reduced pressure to afford 4-(4-Hydroxy-3,5-dimethoxyphenyl)-3-buten-2-one (17) as a yellow powder (61\% yield). ${ }^{1} \mathbf{H}$ NMR $\left(300 \mathrm{MHz}, \mathrm{DMSO}-d_{6}\right): \delta(\mathrm{ppm}) 9.06(\mathrm{~s}, 1 \mathrm{H}, \mathrm{OH}), 7.52(\mathrm{~d}, J=16.3 \mathrm{~Hz}, 1 \mathrm{H}, \mathrm{H} 3), 7.02(\mathrm{~s}, 2 \mathrm{H}, \mathrm{H} 5), 6.72(\mathrm{~d}, J$ $=16.3 \mathrm{~Hz}, 1 \mathrm{H}, \mathrm{H} 2), 3.80(\mathrm{~s}, 6 \mathrm{H}, \mathrm{H} 8), 2.29(\mathrm{~s}, 3 \mathrm{H}, \mathrm{H} 9) \cdot{ }^{13} \mathrm{C}$ NMR $\left(75 \mathrm{MHz}, \mathrm{DMSO}-d_{6}\right): \delta(\mathrm{ppm})=198.0$ (C1), 148.1 (C6), 144.5 (C3), 138.4 (C4), 124.7 (C2), 106.3 (C5), 56.1 (C8), 27.2 (C9). $\lambda_{\max }$ (EtOH, nm) 344. $\varepsilon\left(\mathrm{L} \cdot \mathrm{mol}^{-1} \cdot \mathrm{cm}^{-1}\right): 22593$. Mp: $136-138{ }^{\circ} \mathrm{C}$. HRMS $(\mathrm{m} / \mathrm{z})[\mathrm{M}+\mathrm{H}]^{+}$calcd for $\mathrm{C}_{12} \mathrm{H}_{15} \mathrm{O}_{4}: 223.0970$; found: 223.0963.

\subsubsection{UV Analysis \& Loss of Absorbance (LoA)}

A Cary $60 \mathrm{UV}$-Vis (Agilent) was used to record UV/Vis spectra from initial solutions of the desired compounds at $10 \mu \mathrm{M}$ in ethanol placed in $1 \mathrm{~cm}$ quartz cuvette and are reported in wavelength $(\mathrm{nm})$. Those solutions were then irradiated for one hour in a Rayonet ${ }^{\circledR}$ RPR-200 $\left(\lambda=300 \mathrm{~nm}, \mathrm{P}=8.32 \mathrm{~W} / \mathrm{m}^{2}\right.$, stirring, $\mathrm{T}=35^{\circ} \mathrm{C}$ ) from the Southern New England Ultraviolet Company (Branford, CT, USA) using 14 RPR-3000A lamps. The resulting absorbance was then compared to the initial one and LoA was calculated in percentage at the $\lambda_{\max }$.

\subsubsection{DPPH Inhibition}

Antiradical activities were determined using the 2,2-diphenyl-1-picrylhydrazyl (DPPH) assay to provide $\mathrm{EC}_{50}$ values [33]. To a well containing $10 \mu \mathrm{L}$ of potential antiradical solution in ethanol (concentrations ranging from 400 to $12.5 \mu \mathrm{M}), 190 \mu \mathrm{L}$ of DPPH solution $(\mathrm{C}=200 \mu \mathrm{M}$ in ethanol) was added. Reaction was carried out in a Multiskan FC system (Thermo Fisher Scientific, Waltham, MA, USA) and disappearance of the DPPH radicals was monitored at $520 \mathrm{~nm}$ every 5 min for $7.5 \mathrm{~h}$ in duplicate. The use of different concentrations of potential antiradical gave the $\mathrm{EC}_{50}$ value, which is the quantity needed to reduce half the initial population of DPPH radicals.

\section{Results and Discussion}

As previously described, the most common approach to access $p$-hydroxycinnamates is through the reaction of the corresponding acyl chloride and an alcohol. However, when the desired ester has a free phenol moiety, it is necessary to protect/deprotect it selectively. This last step remains very tedious taking into account $\alpha, \beta$-unsaturated ester moiety sensitivity, and often leads to low yields. To avoid both these protection/deprotection steps and the use of hazardous acyl chlorides, we have developed a two-step synthetic route involving (1) the obtention of a malonic monoester through the opening of Meldrum's acid [34,35], and (2) its subsequent Knoevenagel-Doebner condensation with unprotected syringaldehyde [36] for which various synthetic methodologies have been described in the literature [37-39]. It is worth mentioning that this two-step procedure was carried out without solvent. Indeed, Meldrum's acid turns liquid at $95^{\circ} \mathrm{C}$, playing the role of both reagent and solvent $[40,41]$. This method allowed us to readily access mono-2-ethylhexyl malonate that then underwent Knoevenagel-Doebner condensation with syringaldehyde, in the presence of pyridine and aniline, to provide an octinoxate analogue in sinapic series, 2-ethylhexyl sinapate (1) (Scheme 1). 
<smiles>CCCCC(CC)COC(=O)/C=C/c1cc(OC)c(OC)c(OC)c1</smiles>

Scheme 1. Two-step synthetic pathway leading to octinoxate analogues.

In order to determine the impact of the phenol moiety on the UV absorbance, methylation and acetylation of compound $\mathbf{1}$ were carried out to access compounds $\mathbf{2}$ and $\mathbf{3}$, respectively (Figure 2). Note that compound 2 corresponds to the octinoxate analogue in sinapic acid series.<smiles>CCCCC(CC)COC(=O)/C=C/c1cc(OC)c(OC)c(OC)c1</smiles><smiles>CCCCC(CC)COC(=O)/C=C/c1cc(OC)c(OC(C)=O)c(OC)c1</smiles>

Figure 2. Methylated (2) and acetylated (3) octinoxate analogues with a sinapic acid core.

To evaluate the UV properties of each compound, a UV-Vis spectrum at $10 \mu \mathrm{mol} \cdot \mathrm{L}^{-1}$ in ethanol was performed for each molecule. Spectra are grouped in Figure 3 and compared with octinoxate as a reference.

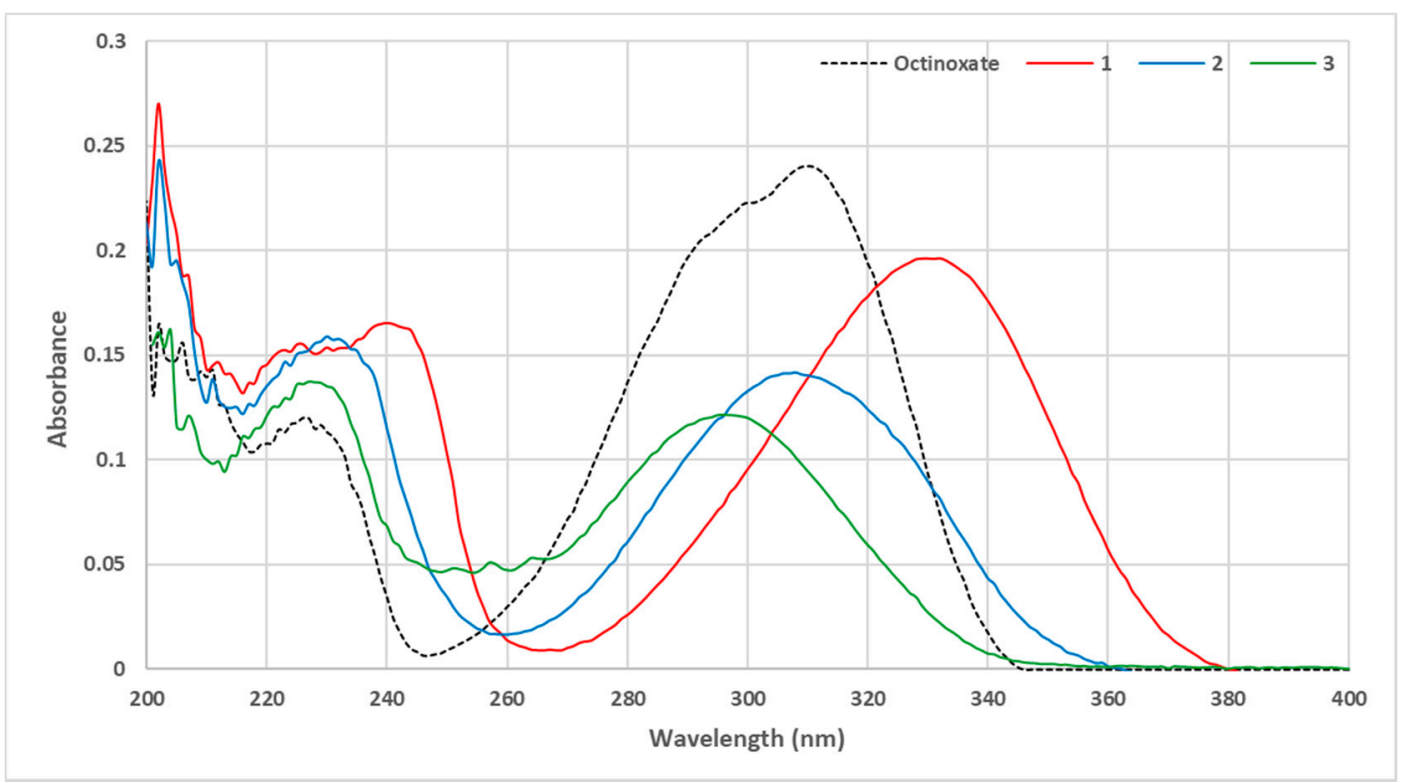

Figure 3. UV Vis spectra of octinoxate analogues bearing sinapic moiety $\left(C=10 \mu \mathrm{mol} \cdot \mathrm{L}^{-1}\right.$ in ethanol).

Unexpectedly, contrary to what could have been assumed from the previous literature [26,27], the use of a sinapic core did not lead to a greater absorbance than that of the coumaric moiety. However, we clearly observed an impact of the phenol protection and that of the protecting group (Me vs. Ac) on the absorbance. Indeed, with the free phenol (compound 1), a hypsochromic shift was observed, giving access to both UVB (280-315 nm) and UVA (315-400 nm) wavelength coverage. The use of an acetate as phenol protecting group (compound 3 ) led to a wavelength coverage area comparable to that of octinoxate, just like methylated compound 2. Nevertheless, there was a slight hypsochromic shift using methylated analogue. In terms of absorbance, the protection of phenol resulted in an important decrease in absorbance. Therefore, if one seeks UV filters with a high absorbance at both UVA and 
UVB wavelengths, it is preferable to use filters with a free phenol. In an attempt to challenge octinoxate in terms of absorbance intensity, our next strategy consisted of modulating the second key structural feature, i.e., the ester moiety. For this, we used the same synthetic route described above with various aliphatic alcohols (compounds 4-9, Figure 4).<smiles>CCOC(=O)/C=C/c1cc(OC)c(O)c(OC)c1</smiles><smiles>COc1cc(/C=C/C(=O)OC(C)C)cc(OC)c1O</smiles><smiles>COc1cc(/C=C/C(=O)OCC(C)(C)C)cc(OC)c1O</smiles><smiles>COc1cc(/C=C/C(=O)OCC2COC(C)(C)O2)cc(OC)c1OC</smiles><smiles>CCCCCCCCCCCCCCCCCOC(=O)C=Cc1cc(OC)c(OC)c(OC)c1</smiles><smiles>CCCCCCCOC(=O)/C=C/c1cc(OC)c(O)c(OC)c1</smiles>

Figure 4. Sinapic acid analogues of octinoxate bearing aliphatic esters.

The absorbance of those six compounds was evaluated at $10 \mu \mathrm{mol} \cdot \mathrm{L}^{-1}$ in ethanol and the UV-Vis spectra were compared to that of octinoxate as reference (Figure 5).

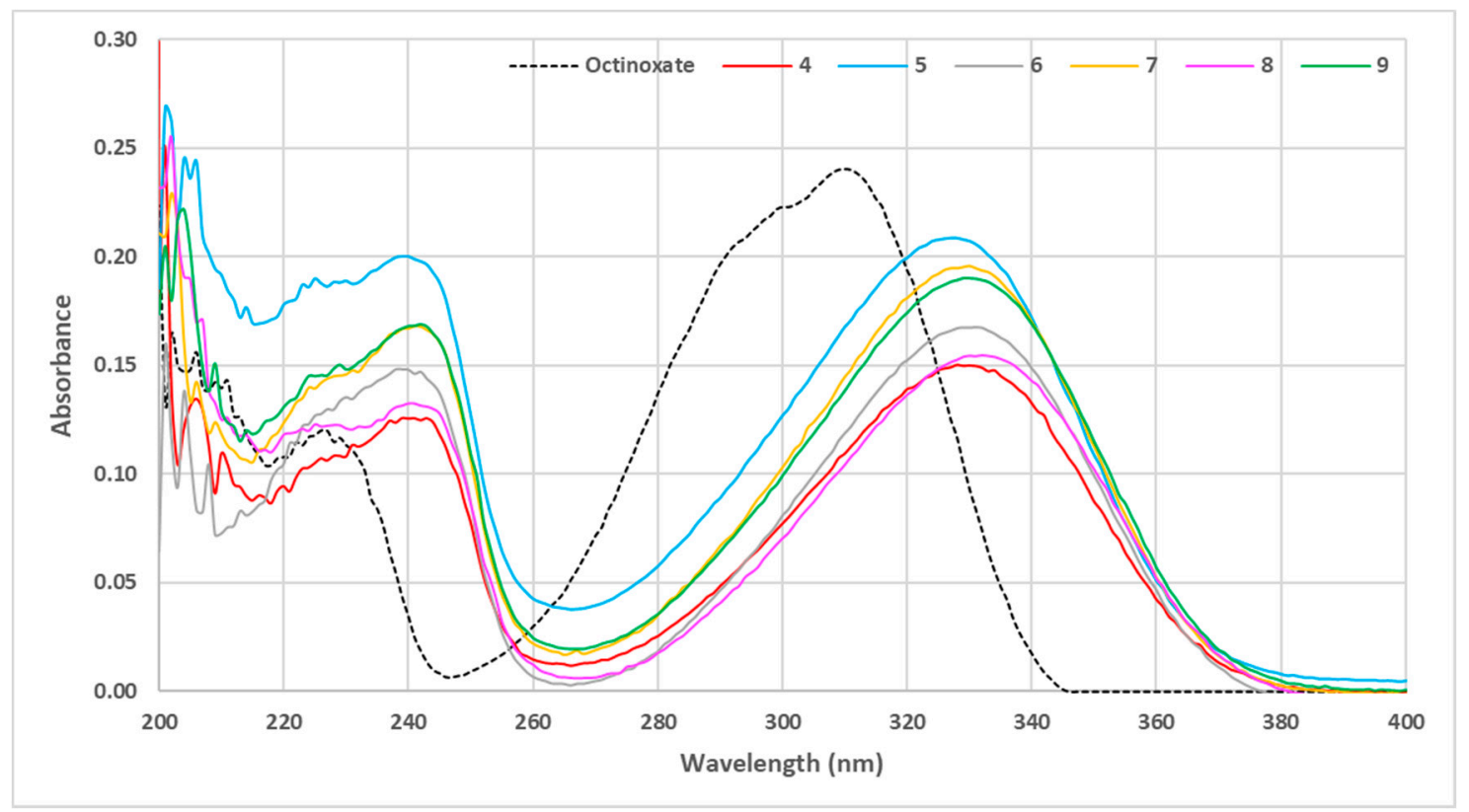

Figure 5. UV visible spectra of aliphatic sinapic acid esters $\left(C=10 \mu \mathrm{mol} \cdot \mathrm{L}^{-1}\right.$ in ethanol).

The use of sparsely sterically hindered primary alcohols led to the esters showing the lowest absorbance spectra (compounds 4 and 8). Fatty alcohols provided a slight increase in the absorbance capacity; however, when the fatty chain was extremely long (compound 6), a loss of intensity compared to moderate chain length (compound 9) was observed. The use of secondary (compound 7) or tertiary alcohol (compound 5) resulted in a gain in absorbance (Figure 5). In summary, the presence of a very bulky ester group resulted in an increase in absorbance. It is noteworthy that such an effect is in accordance with previous studies that highlighted that steric hindrance of the ester moiety was crucial for good UV properties on sinapate, as it promotes the cis/trans isomerization rate of such molecules upon UV exposure [29]. Based on these results, it was decided to continue our study by exploring bulkier phenolic esters 10-14 that were readily prepared using the same two-step synthetic pathway, (Figure 6). 
<smiles>COc1cc(/C=C/C(=O)Oc2c(OC)cccc2OC)cc(OC)c1O</smiles><smiles>COc1ccccc1OC(=O)/C=C/c1cc(OC)c(O)c(OC)c1</smiles><smiles>COc1cc(/C=C/C(=O)Oc2ccccc2C)cc(OC)c1O</smiles><smiles>COc1cc(/C=C/C(=O)Oc2cc(C)ccc2C(C)C)cc(OC)c1O</smiles><smiles>C=CCc1ccc(OC(=O)/C=C/c2cc(OC)c(O)c(OC)c2)c(OC)c1</smiles>

Figure 6. Sinapate analogues of octinoxate bearing phenolic esters.

The UV-Vis absorbance of the five new compounds was determined at $10 \mu \mathrm{mol} \cdot \mathrm{L}^{-1}$ in ethanol. We then compared the spectra obtained with that of octinoxate as a reference (Figure 7).

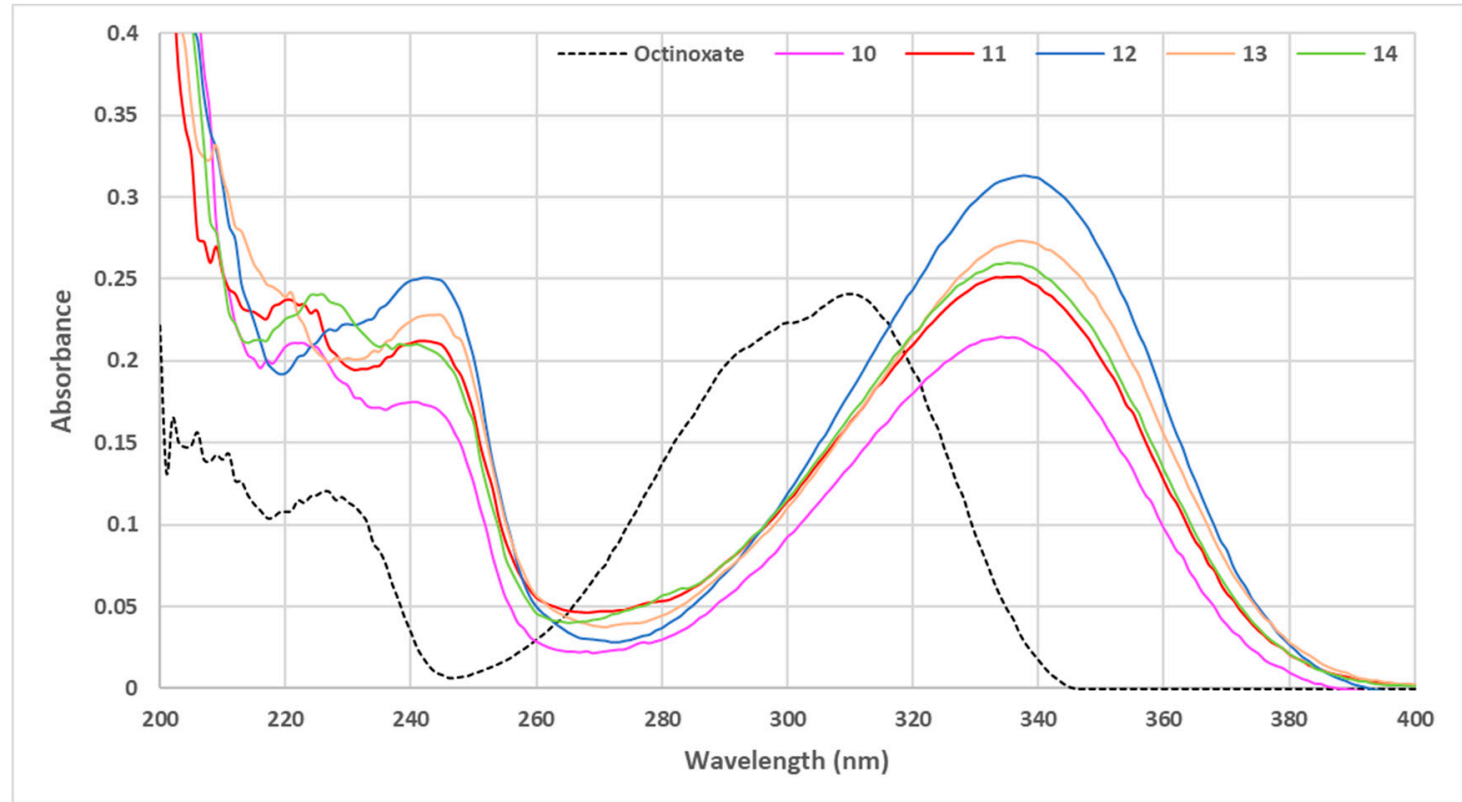

Figure 7. UV visible spectra of phenolic sinapic acid esters $\left(C=10 \mu \mathrm{mol} \cdot \mathrm{L}^{-1}\right.$ in ethanol).

Overall, the use of phenolic ester moiety (PEM) afforded a boost in UV absorbance, even allowing, in some cases, a greater value than octinoxate (Figure 7). Concerning the three different positions of the substitution on the ester aromatic rings (i.e., ortho, meta and para), only the ortho position seemed to induce a significant modification to the absorbance intensity, as the introduction of substituents in the meta (compound 13) or para (compound 14) position did not modify further the absorbance. While the introduction of various steric hindrance to the ortho position of the PEM influenced the level of absorbance for the corresponding compounds, conversely to what we observed with aliphatic sinapate, higher steric hindrance did not result in better absorbance on the ortho position. With a simple methyl group as substituent (compound 12), the resulting absorbance was the best of all synthesized esters. The presence of a methoxy group (compound 11) in place of methyl on the PEM gave similar properties to the meta/para substitutions and finally, substitution at both ortho positions (compound 10) led to the lowest result. If the use of phenolic ester moiety proved that steric hindrance leads to better UV properties, it also highlighted that a too-high hindrance at the ester position (i.e., presence of two bulky groups in ortho positions) negatively impacted the absorbance properties. In conclusion, the steric congestion of the ester group has to be carefully tuned to afford optimal results. 
To go even further, we sought to identify whether the nature of the carbonyl function could also impact the UV absorption. For this, two amide derivatives, as well as a ketone, have been synthesized with a sinapic acid core (compounds 15-17, Figure 8).
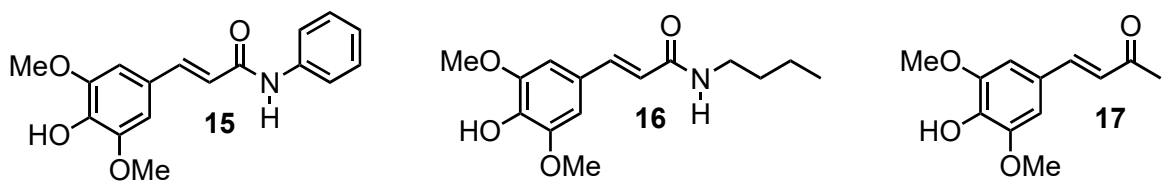

Figure 8. Sinapic acid analogues of octinoxate with amides or ketone groups.

UV-vis spectra at $10 \mu \mathrm{mol} \cdot \mathrm{L}^{-1}$ in ethanol were obtained for compounds $\mathbf{1 5}-\mathbf{1 7}$ and are reported in Figure 9.

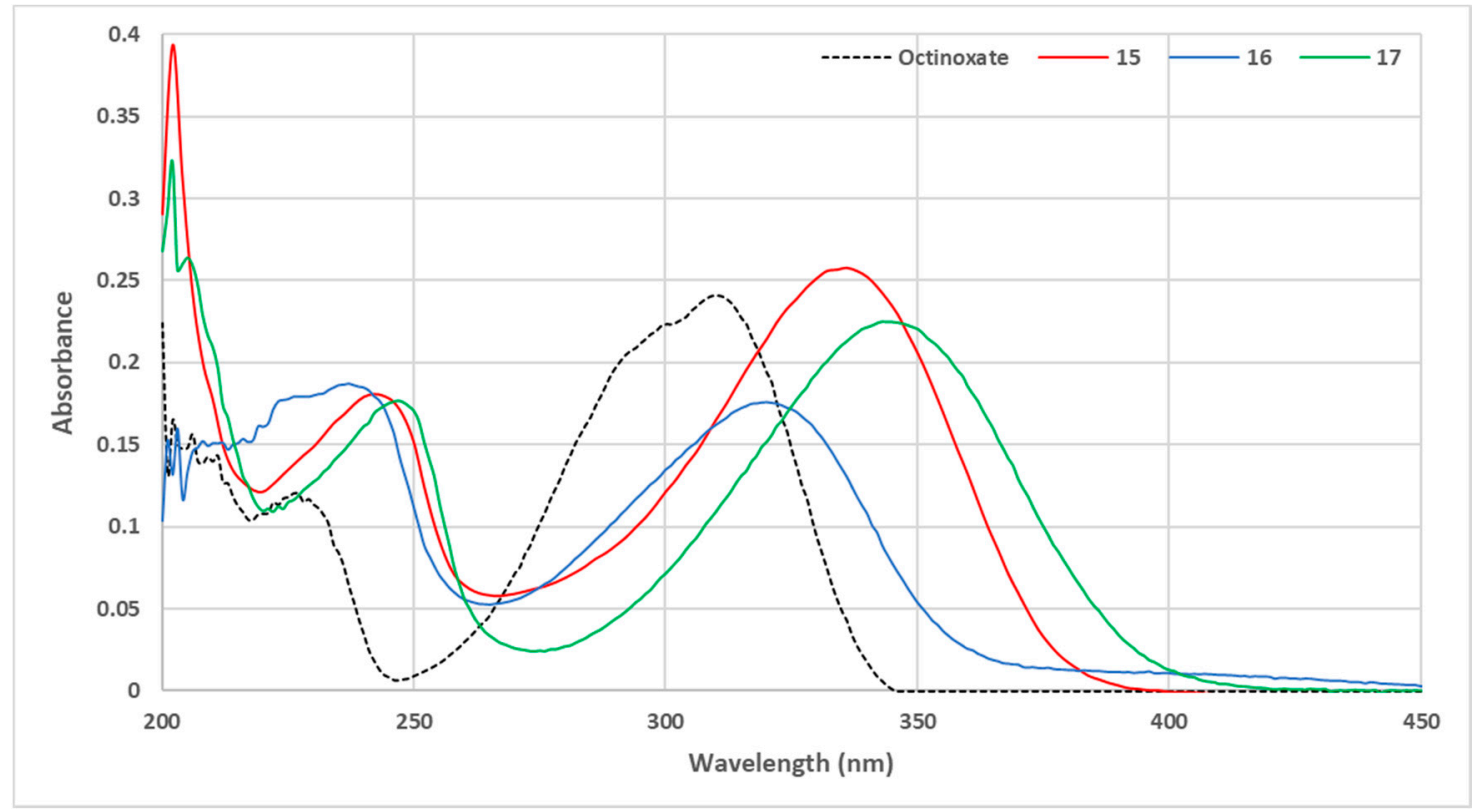

Figure 9. UV visible spectra of sinapic acid amide and ketone $\left(C=10 \mu \mathrm{mol} \cdot \mathrm{L}^{-1}\right.$ in ethanol).

The aniline-based $p$-hydroxycinnamide $\mathbf{1 5}$ showed an absorbance similar to those obtained with phenolic ester (compounds 11-14), thus confirming the importance of steric hindrance on the carbonyl, as previously observed. Aliphatic amide $\mathbf{1 6}$ exhibited an absorbance similar to those of aliphatic esters (compounds 4,6,8). Nevertheless, while the nature of the carbonyl (i.e., ester vs. amide) had no significant impact on the UV properties, the presence of a methyl ketone resulted in a slight bathochromic shift with the level of absorbance similar to the bulkiest aliphatic ester 5 .

The above SARs studies highlight the importance of having a free phenol on the molecule to cover both UVA and UVB wavelengths. Moreover, the steric hindrance at the ester position is essential to obtain a high protection but must be carefully chosen to avoid a negative impact on the absorption of such compounds. The nature of the carbonyl function (ester or amide) is of little importance, although the second one is known to be more stable to hydrolysis. To conclude this study on the UV filtering properties, the photostability of the various compounds was assessed.

\subsection{Loss of Absorbance (LoA)}

In addition to the coverage area and the absorbance intensity, the photostability upon UV irradiation (i.e., loss of absorbance) is important when one seeks alternatives to current UV filters. For this, solutions in ethanol $\left(C=1 \mathrm{mmol} \cdot \mathrm{L}^{-1}\right)$ were irradiated for 60 min under $\mathrm{UV}$ light $(\lambda=300 \mathrm{~nm}, \mathrm{P}$ 
$=8.32 \mathrm{~W} / \mathrm{m}^{2}$, stirring, $\left.\mathrm{T}=35^{\circ} \mathrm{C}\right)$. The absorbance of the resulting solutions was compared to that of the non-irradiated solutions $(t=0)$ to determine the percentage of absorbance loss (Figure 10).

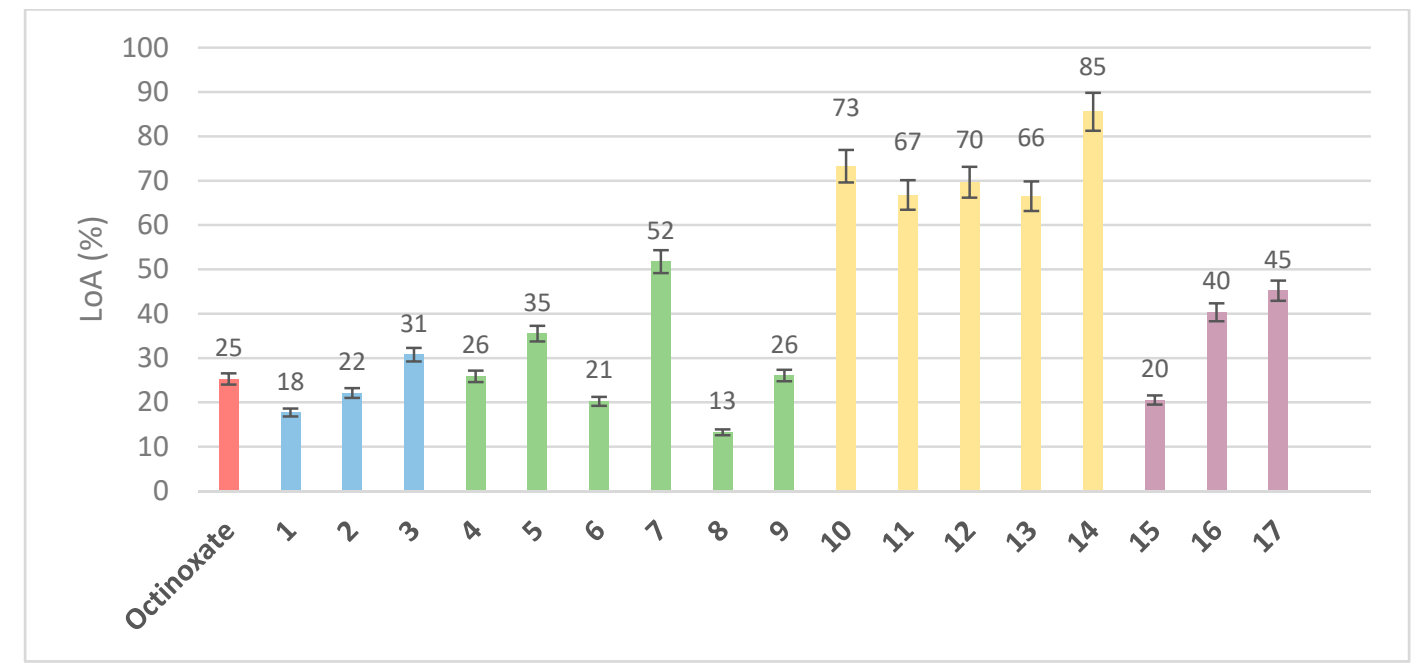

Figure 10. Loss of Absorbance in percentages after UV irradiation $\left(\lambda=300 \mathrm{~nm}, \mathrm{P}=8.32 \mathrm{~W} / \mathrm{m}^{2}\right.$, stirring, $\left.\mathrm{T}=35^{\circ} \mathrm{C}\right)$ for $60 \mathrm{~min}\left(\mathrm{C}=10 \mu \mathrm{mol} \cdot \mathrm{L}^{-1}\right.$ in ethanol): reference (red), octinoxate sinapic based analogues (blue, 1-3), aliphatic sinapic acid esters series (green, 4-9), phenolic sinapic acid esters series (yellow, 10-14) and amide and ketone sinapic acid series (purple, 15-17). Each value is presented with the mean \pm standard error.

When looking at compounds 1-3 (sinapic acid esters octinoxate analogues), it appears that the sinapic core provides identical results than octinoxate in terms of loss of absorbance. Indeed, after $1 \mathrm{~h}$ of irradiation, octinoxate exhibited $25 \%$ loss of absorbance when the sinapic analogue (1) loses $18 \%$ of absorbance. The acetylated analogue (3) and the methylated analogue (2) seemed somewhat worse, since they displayed $31 \%$ and $22 \%$ loss of absorbance, respectively. These results further confirm the need to favor analogues with free rather than protected phenols. With regards to the aliphatic sinapate series (compounds 4-9), one can observe that primary alcohols exhibited interesting photostabilities, close to or better than that of octinoxate, with a loss of absorbance of less than $15 \%$ for compound 8 . Secondary (7) or tertiary (5) alcohols proved to be less photostable, with a loss of absorbance higher than $30 \%$ ( $52 \%$ and $35 \%$, respectively). These results undoubtedly prove that the nature and steric hindrance of the ester moiety play a significant role on the UV filter photostability. As for the phenolic ester series (compounds 10-14), it clearly appeared that these analogues were very unstable toward UV irradiation, as all compounds lost more than $60 \%$ of their initial absorbance. As phenolic esters $\left(\mathrm{R}-\mathrm{CO}_{2}-\mathrm{Ar}\right)$ are known to be easily hydrolyzed [42], one can assume that they are also more prone to photodegradation than aliphatic esters under UV irradiation. Despite their better absorbance properties, phenolic esters proved to be poor candidates as UV filters with regards to their high loss of absorbance, as did the ketone analogue (compound 17), with an intermediate behavior with a loss of absorbance of $45 \%$, which was almost twice as high as octinoxate. Finally, aromatic amide $\mathbf{1 5}$ seemed to be an interesting compromise. Indeed, while the phenolic derivatives collapsed, compound 15 showed an interesting photostability (LoA of 20\%), even better than octinoxate (25\%). However, compared to esters 4-14 where aliphatic moieties led to lower LoA, the trend was reversed for amides. Indeed, the compound with butylamine $\mathbf{1 6}$ was less stable than its analogues in aromatic series (compound 15). It is noteworthy that an in-depth kinetic study of the photostability of all compounds upon UVA/UVB irradiation, as well as the structural elucidation of the potential photoproducts, will be performed and reported in due course.

In order to stabilize sunscreen formulations, but also to protect the skin, antioxidants are usually added to limit Reactive Oxygen Species (ROS) formation at the dermis level and thus maintain 
cellular homeostasis. As multifunctional compounds are increasingly sought after by manufacturers in the cosmetics industry, the last step of this study was to determine whether one or various compounds could be both a potent photostable UV filter and a strong antioxidant to limit the number of ingredients in sunscreen formulations.

\subsection{Antioxidant Activities}

To assess the antiradical potential of the synthesized molecules, tests were performed using DPPH (2,2-diphenyl-1-picrylhydrayl) as a free radical and by monitoring its disappearance. This allowed the determination of $\mathrm{EC}_{50}$ values (half maximal effective concentration), defined as the quantity (in mmol) of synthesized compound needed to reduce $50 \%$ of free radicals. The lower the $\mathrm{EC}_{50}$, the better the antiradical capacity. Once determined, the $\mathrm{EC}_{50}$ values were used to assess the kinetics of the radical scavenging for each compound. To do so, $\mathrm{T}_{\mathrm{EC} 50}$, the time needed to reach the steady state of radical inhibition with a quantity of antiradical corresponding to its $\mathrm{EC}_{50}$, was determined. This parameter allowed the sorting of antiradical properties into three kinetic behaviors: rapid ( $\mathrm{T}_{\mathrm{EC} 50}$ $<300 \mathrm{~s}$ ), intermediate (300 < $\left.\mathrm{T}_{\mathrm{EC} 50}<1800 \mathrm{~s}\right)$ and slow $\left(\mathrm{T}_{\mathrm{EC} 50}>1800 \mathrm{~s}\right)$ as described previously by Sánchez-Moreno et al. [43]. Results are shown in Table 1.

Table 1. $\mathrm{EC}_{50}, \mathrm{~T}_{\mathrm{EC} 50}$ and kinetic behavior of compounds 1-17 for DPPH inhibition in ethanol.

\begin{tabular}{cccc}
\hline Compound & $\mathbf{E C}_{\mathbf{5 0}} \mathbf{( n m o l}^{\mathbf{a}}$ & $\mathbf{T}_{\mathbf{E C 5 0}} \mathbf{( s}^{\mathbf{a}}$ & Kinetic \\
\hline BHA & $6.6 \pm 0.2$ & $>4800$ & Slow \\
BHT & $11.8 \pm 1.3$ & $360 \pm 13$ & Intermediate \\
Octinoxate & $-\mathrm{b}$ & $-\mathrm{b}$ & $\mathrm{b}$ \\
$\mathbf{1}$ & $22.2 \pm 1.1$ & $180 \pm 10$ & Rapid \\
$\mathbf{2}$ & $-\mathrm{b}$ & $-\mathrm{b}$ & $-\mathrm{b}$ \\
$\mathbf{3}$ & $-\mathrm{b}$ & $-\mathrm{b}$ & $-\mathrm{b}$ \\
$\mathbf{4}$ & $18.0 \pm 0.9$ & $360 \pm 18$ & Intermediate \\
$\mathbf{5}$ & $17.0 \pm 0.7$ & $360 \pm 15$ & Intermediate \\
$\mathbf{6}$ & $19.9 \pm 1.0$ & $180 \pm 9$ & Rapid \\
$\mathbf{7}$ & $14.4 \pm 0.4$ & $180 \pm 9$ & Rapid \\
$\mathbf{8}$ & $19.8 \pm 1.0$ & $180 \pm 11$ & Rapid \\
$\mathbf{9}$ & $20.9 \pm 1.1$ & $420 \pm 32$ & Intermediate \\
$\mathbf{1 0}$ & $21.1 \pm 1.1$ & $180 \pm 8$ & Rapid \\
$\mathbf{1 1}$ & $17.1 \pm 0.8$ & $360 \pm 18$ & Intermediate \\
$\mathbf{1 2}$ & $15.3 \pm 0.5$ & $240 \pm 12$ & Rapid \\
$\mathbf{1 3}$ & $13.7 \pm 0.6$ & $480 \pm 24$ & Intermediate \\
$\mathbf{1 4}$ & $19.4 \pm 0.9$ & $<60$ & Rapid \\
$\mathbf{1 5}$ & $8.9 \pm 0.3$ & $600 \pm 40$ & Intermediate \\
$\mathbf{1 6}$ & $15.9 \pm 0.7$ & $240 \pm 12$ & Rapid \\
$\mathbf{1 7}$ & $9.4 \pm 0.4$ & $180 \pm 10$ & Rapid \\
\hline
\end{tabular}

${ }^{\mathrm{a}}$ Each value is the mean \pm standard error, ${ }^{\mathrm{b}}$ no activity observed.

As expected, molecules bearing a protected phenol group (Octinoxate, $\mathbf{2}$ and $\mathbf{3}$ ) did not exhibit any antiradical properties. All tested compounds with free phenol and ester moiety (compounds 1, 4-14) resulted in $\mathrm{EC}_{50}$ within a 13.7-21.1 nmol range. This showed that antiradical activity did not depend on the nature of the ester group (i.e., aliphatic or phenol esters) in a significative manner. However, the introduction of amide (compounds 15 and 16) in place of the ester provided better antioxidant properties. The presence of an anilide (R-CO-NH-Ph) moiety resulted in significantly lower $\mathrm{EC}_{50}$ than the corresponding esters (compounds 10-14), while the aliphatic amide 16 provided a slightly lower value than its ester counterparts (compounds 1, 4-9). The presence of a hydrogen on the amide could explain those results; indeed, it could react with free radicals in addition to the phenol $[44,45]$. Finally, the use of a ketone (compound 17) also provided an interesting EC $_{50}$ close to the one obtained with compound 15. In order to evaluate the potential of the synthesized compounds as antioxidants, 
their $\mathrm{EC}_{50}$ were benchmarked against butylated hydroxyanisole (BHA) and butylated hydroxytoluene (BHT), two molecules commonly used as antioxidants at the industrial scale. Although none of the compounds were better than BHA, compounds 15 and 17 were more active than BHT. Regarding their kinetics, all synthesized compounds reached the steady state of radical inhibition in a maximum of $600 \mathrm{~s}$, exhibiting rapid to intermediate behaviors similar to the BHA reference, and significantly better than BHT, which is a slow antiradical.

In addition to the UV and antiradical properties, the toxicity of such compounds should also be evaluated. It has been observed that the presence of methoxy substituents (-OMe) on the aromatic ring significantly decreased the interaction of molecules with endocrine receptor [46], therefore, the use of a sinapic acid core that possesses two -OMe substituents should result in a lower risk of endocrine disruption. Moreover, previous studies in our laboratory proved the innocuousness of several sinapic acid derivatives towards endocrine receptors $[47,48]$. However, while the sinapic core seems favorable with regards to human health, the impact of the ester moiety on the latter, as well as the possible environmental toxicity of these compounds, should not be overlooked. Such properties will need an in-depth study beyond the preliminary screening of activities reported herein.

\section{Conclusions}

Herein, the synthesis, UV properties, photostability (loss of absorbance upon UV irradiation) and antiradical properties of octinoxate analogues with a sinapic acid core were described. Sinapic acid derivatives with free phenol were synthesized in two steps without the need of protection/deprotection steps, and exhibited absorbance covering both the UVA and UVB regions. The structure-activity relationships study provided insight into the UV properties of synthesized molecules. Absorbance levels and photostability can be fine-tuned by using more or less bulky substituents or by switching to other functions like amides or ketones. However, an extreme degree of steric hindrance proved to have a negative impact. Finally, all compounds with a free phenol provided encouraging $\mathrm{EC}_{50}$ values, with some of them being more active than the industrially used BHT. Sinapate derivatives proved to be multifunctional compounds that could be applied as UV filters and antiradical at the same time in sunscreen formulation.

Supplementary Materials: The following are available online at http://www.mdpi.com/2076-3921/9/9/782/s1; ${ }^{1} \mathrm{H}$ $\&{ }^{13} \mathrm{C}$ NMR spectra and details for all compounds (malonate monoesters and sinapate esters).

Author Contributions: Conceptualization, M.M.M., C.P. and F.A.; methodology, M.M.M. and C.P.; formal analysis, M.M.M. and C.P.; LC-MS² analysis, F.B.; data curation, M.M.M. and C.P.; writing—original draft preparation, M.M.M. and C.P.; writing-review and editing, F.A.; supervision, F.A.; project administration, F.A.; funding acquisition, F.A. All authors have read and agreed to the published version of the manuscript.

Funding: This research was funded by the Agence Nationale de la Recherche, grant number ANR-17-CE07-0046, the European Union's Horizon H2020 Research and Innovation Program, grant agreement number 828753, Grand Reims, Conseil Départemental de la Marne and Région Grand Est.

Conflicts of Interest: The authors declare no conflict of interest.

\section{References}

1. Pillai, S.; Oresajo, C.; Hayward, J. Ultraviolet radiation and skin aging: Roles of reactive oxygen species, inflammation and protease activation, and strategies for prevention of inflammation-induced matrix degradation-A review. Int. J. Cosmet. Sci. 2005, 27, 17-34. [CrossRef] [PubMed]

2. De Gruijl, F.R. Skin cancer and solar UV radiation. Eur. J. Cancer 1999, 35, 2003-2009. [CrossRef]

3. Mohania, D.; Chandel, S.; Kumar, P.; Verma, V.; Digvijay, K.; Tripathi, D.; Choudhury, K.; Mitten, S.K.; Shah, D. Ultraviolet radiations: Skin defense-damage mechanism. Exp. Med. Biol. 2017, 996, 71-87. [CrossRef]

4. Schneider, S.L.; Lim, H.W. A review of inorganic UV filters zinc oxide and titanium dioxide. Photodermatol. Photoimmunol. Photomed. 2018, 35, 442-446. [CrossRef]

5. Serpone, N.; Dondi, D.; Albini, A. Inorganic and organic UV filters: Their role and efficacy in sunscreens and suncare products. Inorganica Chim. Acta 2007, 360, 794-802. [CrossRef] 
6. Siller, A.; Blaszak, S.C.; Lazar, M.; Harken, E.O. Update about the effects of the sunscreen ingredients oxybenzone and octinoxate on humans and the environment. Plast. Surg. Nurs. 2018, 38, 158-161. [CrossRef]

7. Narla, S.; Lim, H.W. Sunscreen: FDA regulation, and environmental and health impact. Photochem. Photobiol. Sci. 2020, 19, 66-70. [CrossRef]

8. Danovaro, R.; Bongiorni, L.; Corinaldesi, C.; Giovannelli, D.; Damiani, E.; Astolfi, P.; Greci, L.; Pusceddu, A. Sunscreens cause coral bleaching by promoting viral infections. Environ. Health Perspect. 2008, 116, 441-447. [CrossRef]

9. Downs, C.A.; Kramarsky-Winter, E.; Segal, R.; Fauth, J.; Knutson, S.; Bronstein, O.; Ciner, F.R.; Jeger, R.; Lichtenfeld, Y.; Woodley, C.M.; et al. Toxicopathological effects of the sunscreen UV filter, oxybenzone (Benzophenone-3), on Coral Planulae and Cultured primary cells and its environmental contamination in Hawaii and the U.S. Virgin Islands. Arch. Environ. Contam. Toxicol. 2015, 70, 265-288. [CrossRef]

10. Ouchene, L.; Litvinov, I.V.; Netchiporouk, E. Hawaii and other jurisdictions ban oxybenzone or octinoxate sunscreens based on the confirmed adverse environmental effects of sunscreen ingredients on aquatic environments. J. Cutan. Med. Surg. 2019, 23, 648-649. [CrossRef]

11. Wang, J.; Pan, L.; Wu, S.; Lu, L.; Xu, Y.; Zhu, Y.; Guo, M.; Zhuang, S. Recent advances on endocrine disrupting effects of UV filters. Int. J. Environ. Res. Public Health 2016, 13, 782. [CrossRef] [PubMed]

12. Eisenstadt, A.; Keren, Y. Process for the Preparation of Octyl Methoxy Cinnamate. U.S. Patent 5187303A, 16 February 1993.

13. Li, F.; Meng, J. Preparing Method and Application of $p$-Methoxy Cinnamate Ester. China Patent 106831415A, 8 August 2012.

14. Hu, W.; Meng, J. Process for the Preparation of Sun Screening Agent 2-Ethylhexyl $p$-Methoxycinnamate. China Patent 105503596A, 20 April 2016.

15. Lin, D.; Yang, Q.-C.; Wang, Y.-F.; Zhang, M.-F. High efficient synthesis of octyl 4-methoxy cinnamate. Huaxue Yu Shengwu Gongcheng 2012, 29, 47-49. [CrossRef]

16. Hamasaka, G.; Ichii, S.; Uozumi, Y. A Palladium NNC-pincer complex as an efficient catalyst precursor for the Mizoroki-Heck reaction. Adv. Synth. Catal. 2018, 360, 1833-1840. [CrossRef]

17. Sharma, Y.O.; Degani, M.S. The Heck reaction of aryl bromides: A green protocol for synthesis of 2-ethylhexyl-4-methoxy cinnamate. Green Chem. Lett. Rev. 2010, 3, 201-204. [CrossRef]

18. Wang, Y.F.; Yang, Q.C.; Zhang, B.J.; Lin, D.; Zhang, M.J. An efficient protocol for synthesis of 4-methoxycinnamate in ionic liquid. J. Indian Chem. Soc. 2013, 90, 489-492.

19. Schutyser, W.; Renders, T.; Bosch, S.V.D.; Koelewijn, S.-F.; Beckham, G.T.; Sels, B. Chemicals from lignin: An interplay of lignocellulose fractionation, depolymerisation, and upgrading. Chem. Soc. Rev. 2018, 47, 852-908. [CrossRef] [PubMed]

20. List, B.; Doehring, A.; Fonseca, M.T.H.; Job, A.; Torres, R.R. A Practical, efficient, and atom economic alternative to the Wittig and Horner-Wadsworth-Emmons reactions for the synthesis of $(E)$ - $\alpha, \beta$-unsaturated esters from aldehydes. Tetrahedron 2006, 62, 476-482. [CrossRef]

21. Yadav, V.G.; Chandalia, S.B. An efficient method for synthesis of 2-ethylhexyl 4-methoxycinnamate, a raw material for the cosmetics industry. Indian J. Chem. Technol. 1999, 6, 19-23.

22. Kumar, V.; Jahan, F.; Kameswaran, K.; Mahajan, R.V.; Saxena, R.K. Eco-friendly methodology for efficient synthesis and scale-up of 2-ethylhexyl-p-methoxycinnamate using Rhizopus oryzae lipase and its biological evaluation. J. Ind. Microbiol. Biotechnol. 2014, 41, 907-912. [CrossRef]

23. Yvergnaux, F.; Forveille, M.; Callegari, J.P. Enzymatic Synthesis of Esters of Cinnamic Acid and Its Derivatives. France Patent 2736354A1, 10 January 1997.

24. Monhaphol, T.; Albinsson, B.; Wanichwecharungruang, S. 2-Ethylhexyl-2,4,5-trimethoxycinnamate and di-(2-ethylhexyl)-2,4,5-trimethoxybenzalmalonate as novel UVA filters. J. Pharm. Pharmacol. 2007, 59, 279-288. [CrossRef]

25. Zeng, Q.-Y. New process for the synthesis of 2-ethylhexyl p-methoxy cinnamate. Huaxue Gongchengshi 2007, 21,13-15.

26. Mention, M.M.; Flourat, A.; Peyrot, C.; Allais, F. Biomimetic regioselective and high-yielding Cu(I)-catalyzed dimerization of sinapate esters in green solvent Cyrene $^{\mathrm{TM}}$ : Towards sustainable antioxidant and anti-UV ingredients. Green Chem. 2020, 22, 2077-2085. [CrossRef] 
27. Horbury, M.D.; Holt, E.L.; Mouterde, L.M.M.; Balaguer, P.; Cebrián, J.; Blasco, L.; Allais, F.; Stavros, V.G. Towards symmetry driven and nature inspired UV filter design. Nat. Commun. 2019, 10, 4748. [CrossRef] [PubMed]

28. Allais, F.; Ducrot, P.-H.; Martinet, S. Straightforward total synthesis of 2-O-Feruloyl-1-malate, 2-O-Sinapoyl-1-malate and 2-O-5-Hydroxyferuloyl-1-malate. Synthesis 2009, 21, 3571-3578. [CrossRef]

29. Dean, J.C.; Kusaka, R.; Walsh, P.S.; Allais, F.; Zwier, T. Plant sunscreens in the UV-B: Ultraviolet spectroscopy of jet-cooled sinapoyl malate, sinapic acid, and sinapate ester derivatives. J. Am. Chem. Soc. 2014, 136, 14780-14795. [CrossRef]

30. Baker, L.A.; Horbury, M.D.; Greenough, S.E.; Allais, F.; Walsh, P.S.; Habershon, S.; Stavros, V.G. Ultrafast photoprotecting sunscreens in natural plants. J. Phys. Chem. Lett. 2015, 7, 56-61. [CrossRef]

31. Jaufurally, A.S.; Teixeira, A.R.S.; Hollande, L.; Allais, F.; Ducrot, P.H. Optimization of the laccase-catalyzed synthesis of $( \pm)$-syringaresinol and study of its thermal and antiradical activities. ChemistrySelect 2016, 1, 5165-5171. [CrossRef]

32. Rodríguez-Padrón, D.; Zhao, D.; Ortega, R.N.G.; Len, C.; Balu, A.M.; Garcia, A.; Luque, R. Characterization and antioxidant activity of microwave-extracted phenolic compounds from biomass residues. ACS Sustain. Chem. Eng. 2020, 8, 1513-1519. [CrossRef]

33. Mishra, K.; Ojha, H.; Chaudhury, N.K. Estimation of antiradical properties of antioxidants using DPPH assay: A critical review and results. Food Chem. 2012, 130, 1036-1043. [CrossRef]

34. Tararov, V.I.; Korostylev, A.; König, G.; Börner, A. Facile preparation and purification of mono tert-butyl malonate. Synth. Commun. 2006, 36, 187-191. [CrossRef]

35. Menezes, J.C.J.M.D.S.; Kamat, S.P.; Cavaleiro, J.A.; Gaspar, A.; Garrido, E.M.J.; Borges, F. Synthesis and antioxidant activity of long chain alkyl hydroxycinnamates. Eur. J. Med. Chem. 2011, 46, 773-777. [CrossRef] [PubMed]

36. Knoevenagel, E. Ueber eine Darstellungsweise der Glutarsäure. Eur. J. Inorg. Chem. 1894, 27, $2345-2346$. [CrossRef]

37. Peyrot, C.; Peru, A.A.M.; Mouterde, L.M.M.; Allais, F. Proline-mediated Knoevenagel-Doebner condensation in ethanol: A sustainable access to p-hydroxycinnamic acids. ACS Sustain. Chem. Eng. 2019, 7, 9422-9427. [CrossRef]

38. Mouterde, L.M.M.; Allais, F. Microwave-assisted Knoevenagel-Doebner reaction: An efficient method for naturally occurring phenolic acids synthesis. Front. Chem. 2018, 6, 426. [CrossRef] [PubMed]

39. Hu, X.; Ngwa, C.; Zheng, Q. A simple and efficient procedure for Knoevenagel reaction promoted by imidazolium-based ionic liquids. Curr. Org. Synth. 2015, 13, 101-110. [CrossRef]

40. Padwal, J.; Lewis, W.; Moody, C.J. Synthesis of the reported structure of crassiflorone, a naturally occurring quinone isolated from the African ebony Diospyros crassiflora, and regioisomeric pentacyclic furocoumarin naphthoquinones. Org. Biomol. Chem. 2011, 9, 3484-3493. [CrossRef]

41. Padilha, G.; Birmann, P.T.; Domingues, M.; Kaufman, T.S.; Savegnago, L.; Silveira, C.C. Convenient Michael addition/ $\beta$-elimination approach to the synthesis of 4-benzyl- and 4-aryl-selenyl coumarins using diselenides as selenium sources. Tetrahedron Lett. 2017, 58, 985-990. [CrossRef]

42. Johansen, M.; Larsen, C. A comparison of the chemical stability and the enzymatic hydrolysis of a series of aliphatic and aromatic ester derivatives of metronidazole. Int. J. Pharm. 1985, 26, 227-241. [CrossRef]

43. Sánchez-Moreno, C.; Larrauri, J.A.; Saura-Calixto, F. A procedure to measure the antiradical efficiency of polyphenols. J. Sci. Food Agric. 1998, 76, 270-276. [CrossRef]

44. Nimse, S.B.; Pal, D.; Mazumder, A.; Mazumder, R. Synthesis of cinnamanilide derivatives and their antioxidant and antimicrobial activity. J. Chem. 2015, 208920. [CrossRef]

45. Son, S.; Lewis, B.A. Free radical scavenging and antioxidative activity of caffeic acid amide and ester analogues: Structure-activity relationship. J. Agric. Food Chem. 2002, 50, 468-472. [CrossRef] [PubMed]

46. Hong, H.; Harvey, B.G.; Palmese, G.R.; Stanzione, J.F.; Ng, H.W.; Sakkiah, S.D.; Tong, W.; Sadler, J.M. Experimental data extraction and in silico prediction of the estrogenic activity of renewable replacements for bisphenol A. Int. J. Environ. Res. Public Health 2016, 13, 705. [CrossRef] [PubMed] 
47. Janvier, M.; Hollande, L.; Jaufurally, A.S.; Pernes, M.; Ménard, R.; Grimaldi, M.; Beaugrand, J.; Ducrot, P.-H.; Allais, F.; Balaguer, P. Syringaresinol: A renewable and safer alternative to Bisphenol A for epoxy-amine resins. ChemSusChem 2017, 10, 738-746. [CrossRef] [PubMed]

48. Peyrot, C.; Mention, M.M.; Brunissen, F.; Balaguer, P.; Allais, F. Innovative bio-based organic UV-A and blue light filters from Meldrum's acid. Molecules 2020, 25, 2178. [CrossRef] [PubMed]

(C) 2020 by the authors. Licensee MDPI, Basel, Switzerland. This article is an open access article distributed under the terms and conditions of the Creative Commons Attribution (CC BY) license (http://creativecommons.org/licenses/by/4.0/). 